\title{
YESUS: TUHAN, GURU DAN TELADAN ORANG PERCAYA
}

Oleh: Stephanus Hartoyo ${ }^{1}$

\begin{abstract}
Education is so important and it has indeed given uncountable contributions upon the development of our world as well as our lives. Through education we are able to equip our children and younger generation with necessary information and skill so that they are ready to face the future. In term of Christian education and spiritual formation, we need to fix our eyes on Jesus. Jesus is Lord, to whom we give our lives and services. He is also our teacher, to whom we learn the truth and implement it in our daily lives. The most important, however, is to follow his example, his humbleness and sincerity. In most cases, when we are talking about education, we have seen numerous talented teachers, but many of them are not able to be good examples. Briefly, a teacher must be able to bring light into the darkness, but also to guide the learners on the right path.
\end{abstract}

Key words : education, teacher, example, Jesus

\section{Pendahuluan}

Sewaktu jurnal ini ditulis, pikiran umat Kristen terfokus pada perayaan hari Lahir Yesus--hari Natal. Para pendeta sedang banyak berkhotbah tentang Inkarnasi Allah menjadi manusia. Tentunya pribadi Yesus menjadi topik paling top dalam suasana ini. Rasanya pas juga bahwa journal ini berbicara tentang Kristologi.

Judul di atas adalah merupakan statemen Yesus sendiri. Ungkapan itu bukan katakata dari orang yang mengagumi atau karena berhutang budi. Kalau Yesus itu nabipembawa suara Tuhan, dan bukan orang yang salah omong, selayaknya kata-kata itu hrs mendapat perhatian khusus dari kita tentang apa makna dan implikasinya bagi kehidupan manusia. Yesus mengkonfirmasi apa yang diucapkan murid-murid-Nya tentang diri-Nya selaku guru dan Tuhan. Yesus menegaskan bahwa sebutan itu akurat, benar atau tepat. Yesus mengatakan bahwa akulah Guru dan Tuhanmu (Yoh. 13:13).

Sebagai guru dan Tuhan bagi para murid-Nya, Yesus dalam kisah ini mengajar melalui perbuatan, teaching by doing... "Jadi jikalau Aku membasuh kakimu, Aku yang adalah Tuhan dan gurumu, maka kamupun wajib saling membasuh kakimu." (13:14) Walau Yesus tahu bahwa segala kuasa ada di tangan-Nya (ayat 3), Dia tidak seperti sikap para murid yang digambarkan Matius di hari-hari terakhir bersama Yesus, bahwa mereka malah sibuk berebut kedudukan dan prestise (Mat. 20:20-28). Sebaliknya, Yesus justru merendahkan diri serendah-rendahnya. Membasuh kaki adalah tugas para budak-- manusia

\footnotetext{
${ }^{1}$ Stephanus Hartoyo adalah pakar dan praktisi di bidang pastoral yang melayani di Gereja Kristen Nazarene lebih dari 30 tahun. Saat ini melayani sebagai Ketua Sekolah Tinggi Theologia Nazarene Indonesia. Menyelesaikan studi S1 di STT Abdiel Ungaran, melanjutkan studi S2 di STTII dan mendapatkan gelar D.Th, dan Ph. D di STT yang sama.
} 
tanpa hak dan tanpa harga serta dipandang sebagai benda. Pembasuhan kaki itu dilakukan bukan saja karena mereka tidak mempunyai budak, walaupun Yesus sebenarnya bisa meyuruh salah satu dari para murid. Namun Dia sendiri melakukannya, sebagai teladan nyata bagi para murid dan orang percaya. Tiga hal yang dibahas dalam tulisan ini adalah Yesus sebagai Tuhan, Yesus sebagai Guru dan sekaligus Yesus sebagai teladan kita. Dua gelar pertama (double titles), adalah gelar khusus yang menunjukkan kualifikasi guru yang sangat mumpuni. "This double titles was not given except to the most accredited teachers. . ."2 Yesus adalah Guru yang tidak ada bandingnya yang merendahkan diri tiada banding agar menjadi teladan bagi siapapun yang mengikuti-Nya.

Apa yang diucapkan dan dilakukan oleh Yesus dalam bagian ini terjadi pada saatsaat terakhir sebelum Dia mengakhiri misi-Nya di bumi Ini berarti bahwa waktu itu sudah sangat pendek, maka hal-hal paling hakiki dan penting harus disampaikan dan bahkan dilakukan-Nya. Kalau kita perhatikan apa yang ditulis oleh Yohanes dalam Injilnya. Halhal sangat penting itu tercermin dalam tulisan itu serta dalam bab-bab seterusnya. Orang yang tahu bahwa waktunya pendek, kesempatannya terbatas, maka dia hanya akan melakukan hal-hal sangat penting. Bagian teks ini sangat penting dan layak untuk digali dan dipelajari, sebab apa yang Yesus katakana dan lakuakan adalah hal yang sangat penting dan menesak.

Ingatlah bahwa setelah peristiwa pembasuhan itu, menurut Rasul Yohanes, maka Yesus akan menghadapi pengkhianatan dan di fasal 18 Yesus ditangkap dan seterusnya berakhir dengan kematian-Nya di kayu salib.

\section{Metode Penelitian}

Dalam pembahasan tema ini, maka penulis melakukannya dengan metode eksposisi. yaitu dengan cara mengekspose, menggali dan mendalami pernyataan Yesus itu dari segi makna katanya. "Exposition n. expounding or explaining." 3 Juga mengaitkan tema ini dengan konteks dan latar belakang peristiwa yang ada dibalik teks itu. Untuk itu maka penulis akan menggalinya dengan bantuan alat bantu seperti ensiklopedi, lexicon dan kamus besar bahasa Indonesia. Disamping itu juga akan membandingkan serta mengambil input dari berbagai versi Alkitab serta berbagai buku tafsiran atau commentary pada teks yang dibahas ini. Dengan itu maka penulis berusaha supaya bahasan ini bukan saja alkitabiah, kontekstual tetapi juga relevan sesuai dengan kebutuhan dan tuntutan zaman.

\section{Pembahasan}

Yesus adalah Tuhan (Kurios)

\footnotetext{
${ }^{2}$ Adam Clark, Holy Bible, containing the Old and New Testament, with a Commentary and Critical Notes, Vol. V (London: Ward, Lock \& CO., Warwick House, Salisbury Square, E.C), John. 13:13.

${ }^{3}$ A.S. Hornby, E.V. Gatenby; H. wakefield, The Advanced Learner's Dictionary of Current English (London: The English Language Book Society and Oxford University Press, 1962), 316,317
} 
Makna dari kata Tuhan (Ing: Lord, master) bukan hanya sekedar sebutan. Istilah ini mempunyai dua arti yaitu pertama, tuan dalam arti relasi antara budak dan tuan, antara bawahan dan pimpinan. Sebutan itu menunjuk kpd orang yang memiliki kuasa atau authority atas seseorang atau benda, karena dia selaku tuan adalah pemilik. Kedua, kurios adalah gelar kehormatan, sebagai wujud hormat dan kekaguman (respect and reverence) yg dilakukan oleh budak kepada tuannya. Murid Yesus juga menyebut Yesus dengan gelar itu. Dalam kenyataan historis kata kurios juga dipakai oleh anak untuk menghormati ayahnya (Mat. 21:30). Pula dipakai oleh rakyat kepada pemimpin/penguasa (magistrates) mereka (Mat. 27:63) bahkan dipakai oleh siapapun yang ingin menghormati seseorang secara khusus (Mat. 8:2,6,8, 15:27 dll). ${ }^{4}$

Secara teologis, gelar itu mempunyai makna yang lebih mendalam karena gelar itu dalam Perjanjian Baru secara specific:

\section{Untuk Allah}

Kurios adalah gelar yang ditujukan kepada Tuhan Allah sebagai pencipta dan penguasa semesta alam. Dalam Perjanjian Lama sebutan itu sepadan dengan kata Elohim dan Yahweh. Perjanjian Baru kata ini dipakai dengan sangat jelas, baik dengan kata sandang, misalnya dalam Mat. 1:22; 5:3, Luk. 1:6,9,28,46; Kis. 7:33 dll), juga dipakai dengan tanpa kata sandang misalnya, Mat. 21:9; 27:10, Mark. 13:20; Luk. 1: 17,38,58,66;1 Pet. 1:25 dll. Bahwa kurios itu adalah TUHAN.

\section{Untuk Mesias -- Yesus sebagai Mesias}

Mesias yang dijanjikan itu disebut Tuhan (kurios) seperti yg disampaikan dalam salam Elisabeth kepada Maria (Luk. 1:43) juga dalam Luk. 2:11; Mat. 21:3; 22:45) dll. Secara jelas gelar Tuhan ditujukan kepada Yesus sebagai Mesias. “..., since by His death He acquired a special ownership in mankind, and after His resurrection was exalted to partnership in the divine administration." Setelah kebangkitan-Nya Thomas menyebut Yesus bukan hanya dengan sebutan Rabbi, tetapi dengan ekspresi khusus: "Ya Tuhanku dan Allahku." (Yoh. 20:28). Sebutan itu banyak didapati dalam Perjanjian Baru (Kis. 1:21; 1 Kor. 7:22; $11: 232$ Kor.5:6, 5:8) dll.

\section{Implikasinya bagi umat}

Karena kita mempercayai Yesus sebagai Mesias dan Tuhan, maka implikasi dari keyakinan atau sebutan itu berarti bahwa kita harus mempercayai, mengasihi, mentaati, menyenangkan-Nya dan melayani-Nya. Sama seperti hamba (doulos) yang tunduk dan taat, maka sikap kita kepada Yesus haruslah seperti itu, bahkan lebih, karena Ia adalah

\footnotetext{
${ }^{4}$ Joseph Henry Thayer, A Greek-English Lexicon of the New Testaments, (Grand Rapids, Michigan: Regency Reference Library, tt.), 365 (diterjemahkan oleh penulis)

${ }^{5}$ Ibid, 366
} 
Tuhan atas segala ciptaan. Mengasihi Tuhan berarti rela berkorban atas waktu, talenta dan harta kita. Kasih kita kepada-Nya harus yang paling unggul, melebihi kasih kita kepada yang lain. Demikian juga dengan ketaatan kita kepada-Nya. "Jikalau kamu mengasihi Aku, kamu akan menuruti segala perintah-Ku (Yoh. 14:16). Ketaatan adalah batu uji akan kasih kita kepada Tuhan. Kasih kepada Tuhan bukanlah hanya merupakan expresi verbal yang sentimental. Janganlah kita mengumbar keinginan daging kita, karena itu akan mendukakan hati Tuhan. Sepantasnya Murid Yesus melayani Dia dengan senang hati, sepenuh hati dan dengan setia dalam segala situasi. Dia layak menerima semua itu sebab Dia dalah Tuhan kita

\section{Yesus adalah Guru (Didaskalos)}

\section{Makna \& historisnya}

Menurut kamus Umum Bahasa Indonesia, "Guru" berarti orang yang kerjanya mengajar. ${ }^{6}$ Dalam sambutan Kusmayanto Kardiman, secara etimologis, kata guru berasal dari dua kata Sanskerta, gu artinya kelapan (darkness) dan ru artinya terang (light), yang berarti bahwa guru adalah orang yang menerangi kegelapan, yang mengusir kebodohan. Menurut konteksnya, maka sebutan guru dalam teks yang kita bahas ini berhubungan dengan orang yang mengajarkan Firman Allah. Dalam kehidupan umat Israel, sebutan itu biasanya dipakai istilah Rabbi. Yesus juga sering dipanggil oleh orang-orang pada zaman itu dengan sebutan Rabbi atau guru (Mat. 26:18; Mark. 5:35; Luk. 8:49; Yoh 11:28). Didaskalos, a teacher, in the N.T. one who teaches concerning the things of God and the duties of man....2. of the teachers of the Jewish religion (Luk.2:46; Yoh. 3:10)....6. of those who in the religious assemblies of Christians undertook the work of teaching, with the special assistance of the Holy Spirit (1 Cor.12:28; Eph. 4:11; Act. 13:1,cf. Eph. 4:11). ${ }^{7}$

Bahasan ini tentunya ditekankan kepada guru yang mengajarkan Firman Allah. Sebab guru sebagai pengajar adalah merupakan salah satu bidang pelayanan yang memang sudah ada sejak dahulu, sebagaimana lazim diantara orang Israel. Di samping itu, Paulus juga menyebutkan secara specific mengenai jabatan itu dalam Efesus 4:11, walaupun tugas itu sebenarkan menyatu dengan tugas seorang penggembala, hal itu terlihat dari teks yang tertulis dalam bahasa Yunaninya.

Jabatan sebagai guru, dalam Perjanjian Baru tidak bisa dipisahkan dengan jabatan sebagai penilik Jemaat. Sebab salah satu tugas dan kriteria seorang penilik Jemaat adalah bahwa ia harus cakap mengajar orang (1 Tim. 3:2c). Seorang guru yang mengajar kebenaran Firman Tuhan haruslah seorang yang memenuhi kriteria akademik (menguasai materi dengan baik serta menyampaikannya dengan cara yang sistimatik dan logis) dan moral-etik sehingga ia diterima, didengar dan diikuti oleh para pendengarnya. Itu alasannya Yesus bersifat sangat kritikal terhadap para Ahli Torat dan orang Farisi, sebab

\footnotetext{
${ }^{6}$ W.J.S. Poerwodatminto, "Guru” dalam Kamus Umum Bahasa Indonesia, (Jakarta: Balai Pustaka, 1967), 335

${ }^{7}$ Hornby, The Advanced Learner's Dictionary of Current English, 317.
} 
walaupun mereka sangat menguasai Hukum Torat bahkan sampai detail, namun mereka tidak mau melakukan atau mengimplementasikan apa yang mereka ajarkan dalam hidup mereka sendiri (Mat. 23).

Yesus mengajar dengan kuasa, otoritas, namun bukan hanya itu daya kagum pendengarnya. Salah satunya adalah karena pendengar tidak melihat cacat dalam dirinya. Intergritasnya teruji sempurna. Dia tidak hanya fasih mengajar tentang kebenaran yang relevan dengan metode menarik, tetapi karena apa yang diajarkan juga dipraktekkan-Nya.

Dalam ilmu pendidikan modern, maka seorang guru dituntut untuk menguasai content yang disampaikannnya. Ia harus mengaplikasikannya sesuai konteks yang ada, sehingga karakter pendengar dibentuk dan para pendengar (murid) mendapatkan kompetensi seperti yang diharapkan. Ini adalah filosofi dalam sistim pendidikan teologi dalam Gereja Kristen Nazarene Internasional yang dikenal dengan 4Cs (Content, context, competency dan Character).

Zaman telah berubah, kemajuan dalam segala bidang terjadi sedemikian cepat. Akibatnya, maka guru harus memahami banyak hal, bukan saja bidang yang ditekuninya, tetapi juga harus mengerti metode pengajaran, ilmu komunikasi, ilmu jiwa dan untuk sekarang harus bisa menggunakan tekhnologi informatika. Seorang pemrasaran dalam suatu seminar pendidikan dalam menyampaikan materi yang dipersiapkan hanya menggunakan handout fotokopi dan pendengar kemudian kehilangan minat dengarnya. Moderator mengakhiri sessi itu dengan komentar "paparan ini walau materinya bagus tetapi garingan," Guru memang dituntut kreatif, apalagi tekhnologi informasi melalui internet sudah menjangkau kemana-mana.

Dalam Mata Kuliah Effective and Creative Teaching, yang diampu oleh Prof. James Thames, Ph.D., salah satu bahasan diskusinya adalah bahwa guru harus memiliki apa yang disebut pathos, ethos dan logos. Pathos adalah kualitas dalam berbicara yang bisa mempengaruhi atau merangsang perasaan pendengar. Ethos mengacu kepada otoritas/kelayakan guru dimata para muridnya. Apakah sebagai guru ia layak, apakah ia dewasa, apakah ia mempunyai pengalaman yang memadai dan apakah reputasinya tidak tercela. Sedangkan logos dalam hal ini berhubungan dengan adanya kesatuan dan kesimpulan antar subjek dan argument-argumen sang guru. Pendidikan atau pengajaran yang berhasil dimulai dari kepercayaan murid terhadap gurunya. Karena itu guru seharusnya bukan hanya menjadi profesi, tetapi menjadi panggilan hidup yang diyakini dan digeluti demi umat atau muridnya.

Yesus adalah guru yang sempurna yang mengajarkan kebenaran ilahi dan hal-hal rohani dengan utuh secara verbal maupun non verbal. Dia tidak hanya menhgajar dengan otoritas, tetapi juga dg keteladanan, kasih dan pengorbanan.

\section{Implikasinya}

Apabila kita memperhatikan kata-kata Yakobus tentang jabatan guru, seharusnya orang tidak sembarangan menjadi guru agama Kristen. Apapun motivasinya orang menjadi guru, orang harus hati-hati untuk mengambil dan mengemban tugas itu. “... sebab kita tahu, bahwa sebagai guru kita akan dihakimi menurut ukuran yang lebih berat." (Yak. 3:1). 
Pada masa kini, dalam konteks Indonesia, saya agak prihatin bila berbicara mengenai "profesi" guru. Sebab dahulu guru dilihat dengan sebelah mata, karena sejak dahulu guru selalu dipandang sebagai pekerjaan yang kering-miskin. Sejalan dengan perubahan waktu dan perhatian Pemerintah terhadap dunia pendidikan, maka sekarang ini guru mendapat perhatian berlebih secara kesejahteraan. Guru menerima gaji extra, yaitu bagi yang telah lulus sertifikasi sebagai guru, maka yang bersangkutan akan mendapat tunjangan $100 \%$ dari gaji pokoknya. Akibatnya, banyak orang yang ingin menjadi guru, bukan karena panggilan, tetapi karena uang dan imbalan.

Dalam konteks guru yang mengajarkan Firman Tuhan, maka seharusnya motivasinya harus benar, kerjanya harus memadai dan selalu mau belajar untuk lebih baik. Dalam realita dan interelasi dengan banyak Guru Agama Kristen, maka ada banyak guru tidak tetap yang dedikasinya sangat mengagumkan. Banyak guru-guru tidak tetap yang mengajar di beberapa sekolah, mengajar hanya dua atau tiga murid di satu Sekolah Dasar walaupun honorariumnya hanya cukup untuk BBM dan keperluan mandi-cuci. Guru-guru ini ingin melayani dan mengkomunikasikan Firman Tuhan kepada anak didik mereka. Itulah pelayanan mulia, bagi anak bangsa sekaligus sebuah dedikasi bagi Yang Maha Tinggi.

Dengan dedikasi dan komitmen, maka diharapkan bahwa para guru bisa mengajar dengan baik dan menghindari salah satu aspek apa yg disebut oleh Mohandas K. Gandhi dalam The Seven Social Sins, yaitu "knowledge without character" (pendidikan tanpa karakter). ${ }^{8}$ Apabila karakter diabaikan dalam pendidikan, maka pendidikan itu akan gagal dan bangsa akan runtuh karenanya. Cara paling ampuh dalam membentuk karakter bagi para murid adalah melalui keteladanan. Kini dalam dunia pendidikan di negeri kita sedang banyak dibicarakan tentang pendidikan yang berkarakter. Tanpa karakter, maka masalah bangsa, seperti korupsi dan berbagai tidak kriminal akan makin sulit diatasi.

\section{Yesus adalah Teladan (Hupodaigma)}

Kata teladan menurut Kamus Umum bahasa Indonesia berarti sesuatu (perbuatan, barang dsb) yang patut ditiru. ${ }^{9}$ Menurut Lexicon, kata hupodaigma salah satu artinya adalah an example. ${ }^{10}$ Jabatan sebagai guru tdak bisa dipisahkan dari peranan guru itu sendiri sebagai teladan. Dalam banyak hal di masa sekarang ini, krisis yang sering terlontar adalah krisis keteladanan. Banyak pemimpin yang pandai, cerdas dan trampil dalam bidang kehidupan, tetapi ternyata banyak pemimpin yang gagal, alasannya adalah karena pemimpin itu tidak bisa menjadi teladan. Pemimpin hanya bisa omong saja, memberi instruksi atau perintah, tetapi dia sendiri tidak melakukannya. Dalam konteks pengajaran, kegagalan guru masa kini adalah kalau ia hanya bisa mengajar, tetapi tidak mampu untuk memberikan teladan. Hal ini mutlak perlu dalam perspektif guru yg mengajar firman Tuhan khususnya, dan secara umum bagi siapapun yang menyandang predikat guru.

\footnotetext{
${ }^{8}$ mkgandi.org

${ }^{9}$ W.J.S. Poerwodatminto, Kamus, 1036.

${ }^{10}$ Joseph, A Greek-English, 642
} 
Memang kadang masyarakat mnuntut guru secara tidak realistis. "Guru dituntut menjadi sosok yang 'super duper'.... ke posisi yang serba bisa....tidak boleh cacat... harus multitalenta dan multikompetensi. Padahal memang bukan bidangnya." 11 Sesungguhnya guru tidaklah manusia super, seharusnya dia tidak dituntut untuk tahu segala macam dan bisa melakukan segala macam. Tetapi kebenaran intrinsic yang tidak bisa disangkali adalah bahwa guru harus bisa menjadi teladan dalam kata, tingkah dan perbuatan. Dalam hubungannya dengan posisi guru yang mengajar Firman Tuhan, maka menjadi teladan adalah keniscayaan. Gambaran situasi umat Israel yang ada dalam Kitab nabi Yesaya 9 adalah situasi moral dan kehidupan masyarakat yang rusak, penyebabnya adalah karena para nabi, tua-tua yang tidak bisa menjadi teladan. "... sebab sekaliannya mereka murtad dan berbuat jahat, dan setiap mulut berbicara bebal." (Yes. 9:16b).

Para murid yang melihat guru sebagai teladan akan membuat ketaatan, kekaguman dan sekaligus menyentuh kalbu para muridnya. Apalagi kalau guru itu melakukan sesuatu yang mulia, sebagai pribadi yang dikagumi, tetapi mau merendahkan diri, seperti yang dilakukan Tuhan Yesus kepada para murid-Nya. Di sini murid tidak hanya mengerti sesuatu, tetapi terdorong untuk melakukan hal yang sama. Dengan teladan dari Guru, maka murid akan mengalami perubahan terhadap suatu sudut pandang, mengalami perubahan paradigm tentang guru itu sendiri. Teladan itu menjadi pelajaran yang akan terpatri di hati, sulit untuk diingkari, sulit untuk dilupakan.

Dalam konteks Jawa, guru hrs bisa digugu \& ditiru. Guru adalah figure panutan... pribadi yang bisa di percaya atas apa yang dikatakan, apa yang diajarkan bukan hanya menyangkut keilmuan dan pengetahuan, tetap juga menyangkut etika dan moralnya. Tidak cukup seorang guru mempunyai pengetahuan tinggi dan ketrampilan (skill) yang baik, apalagi hanya memamerkan gelar akademik yang selalu melekat di depan atau belakang namanya. Guru harus bisa digugu, artinya apapun yang diajarkan haruslah sesuatu kebenaran yang bisa dipercaya, kalau tidak maka guru itu tidak trustworthy, alias pembohong dan munafik. Dalam konteks ini guru dituntut competent and discipline, serta menjadi contoh atau teladan. Tanpa competency dan discipline maka seseorang tidak bisa menjadi guru. Guru yang memenuhi harapan umat, maka kedua aspek itu musti ditambah satu, yaitu keteladanan. Guru itu harus bersifat exemplaris.

Untuk bisa mewujudkan ketiga aspek di atas, maka guru dituntut juga menjaga kemurnian (authenticity), keteguhan hati (consistency) Juga harus menjunjung kesederhanan (simplicity) dan kejujuran (honesty)- seharusnya guru selalu mengingat aspek ini, jangan ada yang menjadi plagiat misalnya. Guru juga harus mempunyai integritas (quality of being honest and upright in character) ${ }^{12}$ dan rendah hati (humility) jangan arogan. Jangan sok pintar, sok tahu, walaupun ia sesungguhnya pintar dan banyak tahu. Manakala kualitas di atas ada, guru bukan hanya dikagumi dan dipercaya, guru akan bahkan ditiru oleh para muridnya. Ekstreemnya bahkan cara bicara, pakaian dan kebiasaannya ditiru oleh muridnya. Sebaliknya bila guru gagal menampilkan karakter yang baik, maka murid akan menjadi lebih buruk daripada gurunya. Guru yang melakukan cela

\footnotetext{
${ }^{11}$ Tajuk rencana Koran Harian "Kedaulatan Rakyat” 28 Nopember, 2008.

${ }^{12}$ A.S. Hornby, The Advanced Learner's Dictionary of Current English, $2^{\text {nd }}$ Edition, 513.
} 
sedikit akan menhasilkan cela yang lebih besar dalam hidup muridnya. Seperti tercermin dalam pepatah: "guru kencing berdiri, murid kencing berlari."

Dalam konteks Filosofi Pendidikan Nasional, menurut Ki Hadjar Dewantara, peranan guru harus bisa "ing ngarsa sung tulada, ing madya mangun karsa, tut wuri handayani." Bila guru berada di hadapan para murid, maka ia harus menjadi teladan, bila berada diantara mereka guru memberikan dorongan (to encourage) dan bila guru berada di belakang, dia memberikan dukungan (support). Murid kadang kala gagal memahami apa yang didengar secara verbal, maka guru melakukannya secara nyata, teaching by doing, dan murid akan mengikutinya. Tidak cukup kalau murid hanya mendengar harus begini dan begitu, jangan lakukan ini, jangan lakukan hal itu. Guru harus memraktekkannya. Kadang kala murid putus asa, malas, merasa terlalu sulit menyelesaikan tugas guru. Maka guru harus bisa memberikan dorongan bahwa murid itu bisa. Janganlah sebaliknya guru mematahkan semangat para murid, apalagi mengolok-olok sebagai anak desa yang bodoh. Guru harus mengatakan: "kau pasti bisa!!." Apabila murid sudah berusaha dan ternyata masih ada kesulitan, maka guru itu akan berkata: "saya siap membantu untuk mencari solusi bagi kesulitanmu, kau bisa mencari aku bahkan kalau perlu datang kerumahku, kapan saja."

Bukankan itu juga yang dilakukan oleh Yesus? Dia tidak hanya mengajar orang tentang kasih, tetapi Dia melakukannya, bahkan rela berkorban, rela mati bagi umat manusia yang dikasih-Nya (Mark. 10:45). Kepada para murid Dia memberikan dorongan dan bahkan mengatakan bahwa mereka akan melakukan perkara-perkara yang lebih besar dibanding yang Dia lakukan (Yoh.14:12). Implikasi dari kata-kata itu ialah bahwa Yesus memberikan dorongan kepada murid-murid-Nya bahwa mereka bisa melakukan hal-hal ajaib seperti yang Dia lakukan, bahkan lebih besar. Yesus pula berjanji, tidak akan meninggalkan mereka sebagai yatim piatu, Dia akan kembali dan memberikan penyertaan dan pertolongan-Nya melalui Roh Kudus. Roh Kudus itu diberikan lengkap dengan kuasa dan karunia-karunia rohani yang lain (Yoh. 14:15-18, 16:13-18; 1 Kor. 12). Dengan demikian maka misi dan tugas pemberitaan dan pengajaran akan terus berlangsung dengan baik dan berhasil.

\section{Kesimpulan}

Akhirnya, haruslah kita sadarai bahwa tekhnologi berkembang pesat dan para guru wajib memahami dan memanfaatkanya. Di samping itu ilmu pengetahuan makin luas dan kita layak mengelutinya, serta tak henti-hentinya belajar. Namun keberhasilan pengajaran dan pemberitaan iman Kristen bukanlah tergantung kepada semata-mata kepada tekhnologi dan ilmu pengetahuan, melainkan utamanya bertumpu kepada tiga hal di atas, yaitu keyakinan kita kepada Yesus sebagai Tuhan, kerelaan untuk belajar dari guru kita yaitu Yesus serta berjalan mengikuti teladan-Nya. Mengikuti teladan-Nya adalah gaya hidup injili dan menyenangkan hati Yang Maha Tinggi. 


\section{DAFTAR PUSTAKA}

Clark, Adam. Holy Bible, containing the Old and New Testament, with a Commentary and Critical Notes, Vol. V. London: Ward, Lock \& CO., Warwick House, Salisbury Square, E.C. John. 13:13.

Hornby, A.S., Gatenby, dan lainnya. The Advanced Learner's Dictionary of Current English . London: The English Language Book Society and Oxford University Press, 1962.

Poerwodatminto, W.J.S. Kamus Umum Bahasa Indonesia. Jakarta: Balai Pustaka, 1967.

Thayer, Joseph Henry. A Greek-English Lexicon of the New Testaments. Grand Rapids, Michigan: Regency Reference Library, tt. 